\title{
海底表層堆積物を対象とした酵素触媒法に よる底泥の巻き上がり抑制技術の適用性評価
}

\author{
村田 湧水 1 ・畠 俊郎 2 -鍵本 慎太郎 3 - 松村 $\quad$ 聡 4 - 水谷 崇亮 5 \\ 1 学生会員 富山県立大学大学院工学研究科環境工学科専攻（广939-0398 富山県射水市 黒河 5180) \\ E-mail: 1757011@st.pu-toyama.ac.jp \\ 2 正会員 富山県立大学教授 工学部環境・社会基盤工学科（广939-0398 富山県射水市 黒河 5180） \\ E-mail: t-hata@pu-toyama.ac.jp \\ 3 港湾空港技術研究所（广239-0826 神奈川県横須賀市 長瀬 3-1-1） \\ 4 正会員＼cjkstart港湾空港技術研究所（干239-0826 神奈川県横須賀市 長瀬 3-1-1） \\ 5 港湾空港技術研究所（广239-0826 神奈川県横須賀市 長瀬 3-1-1）
}

\begin{abstract}
これまでに，チュニジア国のイシュケウル湖を対象とした試験結果から，原位置微生物由来の酵素と 天然由来の固化試薬を用いた表層固化から表層堆積物の再懸濁抑制効果が明らかとなっている. 本研究 では，この技術の適用範囲拡大を目的に，酵素そのものを用いることで施工期間の短縮効果を期待する こととした．対象として国内表層堆積物を選定し，提案技術の有効性検証を目的として短期・長期で固 化効果を得ることを目的とした 2 種類の室内試験を実施した。試験の結果より, 国内表層堆積物と酵 素製剂を用いた場合においても濁度抑制効果が期待できることが明らかとなった。また，底泥表層に析 出したカルサイトの膜厚と強度に正の相関があることと, X 線 CT 撮影の結果から析出したカルサイ 卜膜と底泥の間に隙間が生成されることなどが明らかとなった。
\end{abstract}

Key Words : Urease activity, X-ray CT, carbonate precipitation, vane shear test, surface strength

\section{1. はじめに}

底泥の巻き上がりは台風の来襲や高波浪，潮流，水深 が浅い地域によっては風などによって発生することが知 られている ${ }^{1)}$. この底泥の巻き上がりによる土砂流出や 海底に堆積した栄養塩の再浮遊による污染源拡大等の問 題が東南アジア沿岸，有明海等で生じているとともに, その対策技術が求められている ${ }^{2)}$. チュニジア国の世界 自然遺産であるイシュケウル湖の底泥を対象とした検討 結果から，原位置にすでに生息している微生物由来の酵 素と，固化効果を期待した尿素・塩化カルシウムを主体 とする固化試薬を湖沼底泥に添加することによって，炭 酸カルシウムの結晶を底泥表面に析出させる効果が明ら かとなっている．この底泥表層に析出したカルサイトの 膜により表層堆積物の再懸濁を抑制する効果が報告され ている ${ }^{3)}$. 本研究では，この表層固化技術の適用範囲拡 大を目的とし，対象となる底泥内にすでに生息している 微生物種に影響されることなく固化効果が期待できる酵 素製剂そのものを用いた場合の有効性について国内表層 堆積物を対象とした室内試験の結果に基づき考察するこ ととする.

\section{2. 実験概要}

（1）酵素触媒を用いた固化メカニズム

本研究では, 反応触媒として酵素製剂（ナタ豆由来の ウレアーゼ）を用いることとした．尿素の加水分解によ って発生する炭酸イオン $\left(\mathrm{CO}_{3}^{2-}\right)$ と, 別途添加した塩化 カルシウム由来のカルシウムイオン $\left(\mathrm{Ca}^{2+}\right)$ が底泥表面で 結晶化し，炭酸カルシウム（以下，カルサイト）の膜を 底泥表層に生成する効果を期待している．この底泥表層 に析出したカルサイトの膜により風波などによる表層堆 積物の巻き上がりを抑制することで濁度を低下させる効 果を期待している. 本研究で着目した反応のうち, ウレ アーゼによる尿素の加水分解を式(1)，カルサイトが結晶 化するメカニズムを式(2)にそれぞれ示す。

$$
\begin{gathered}
\mathrm{CO}\left(\mathrm{NH}_{2}\right)_{2}+2 \mathrm{H}_{2} \mathrm{O} \rightarrow 2 \mathrm{NH}_{4}^{+}+\mathrm{CO}_{3}^{2-} \\
\mathrm{Ca}^{2+}+\mathrm{CO}_{3}^{2-} \rightarrow \mathrm{CaCO}_{3} \downarrow
\end{gathered}
$$

\section{（2）実験に用いた各試料}

本研究では，固化溶液と酵素製剤を添加し，底泥表層 にカルサイト膜を析出させる溶液試験を行い，濁度低下 に与える提案技術の有效性を室内試験により検証した. 試験は $0.15 \mathrm{~mol} / \mathrm{L}$ 濃度の尿素および塩化カルシウム溶液 
と $0.07 \mathrm{~g} / \mathrm{L}$ の低濃度の酵素製剤を添加した条件で，環境 負荷を軽減させることを目的とした長期施工（以下，長 期試験）について 3 ケースの供試体を作製した．合わせ て，尿素および塩化カルシウム溶液の濃度を $0.30 \mathrm{~mol} / \mathrm{L}$ 之酵素製剂の濃度を $4.00 \mathrm{~g} / \mathrm{L}$ に変更し, 短期施工 (以下, 短期試験）を目的とした 2 ケースの供試体を作製した. 長期試験では, 底泥表層に添加した溶液中の $\mathrm{NH}_{4}{ }^{+}$および $\mathrm{Ca}^{2+}$ 濃度を測定し, 尿素の加水分解及びカルサイトの析 出が行われているかの確認を行った. 加えて, 底泥の巻 き上がり抑制の有効性を検討するための濁度試験，表層 に析出したカルサイトの強度を測るためのテンションメ 一ターによる強度測定，固化処理後における底生生物一 の影響評価を行うためのベーンせん断試験を行った. 短 期試験では, 添加した溶液の $\mathrm{NH}_{4}{ }^{+}$および $\mathrm{Ca}^{2+}$ 濃度の測定, テンションメーターによる強度の測定, CT 撮影による 底泥表層に生成されたカルサイト膜の観察を行った。

表-1に各試験で用いた溶液の組成，酵素製剤（ウレア 一ゼ)の添加量を示寸. サンプル $\mathrm{A} \sim \mathrm{C}$ は長期試験， D, $\mathrm{E}$ は短期試験を対象としている. サンプル A は尿素, 塩 化カルシウムのみを用い，底泥内にすでに生息している 原位置微生物の働きにより底泥表層にカルサイトを析出 させる効果を期待している. サンプル B はサンプル A に反応触媒である酵素（ウレアーゼ）を添加しており， 短期間での固化効果を期待している. サンプル C はサ ンプル B に NutrientBroth や塩化アンモニウム, 炭酸水 素ナトリウムを加えており, 添加した酵素とあわせて原 位置由来のウレアーゼ活性陽性微生物の活性化による固 化効果の促進を期待している. なお， サンプル A D に おける尿素, 塩化カルシウムの濃度はそれぞれ 0.15 $\mathrm{mol} / \mathrm{L}$ であり, サンプル $\mathrm{E}$ のみ尿素と塩化カルシウムの 濃度は $0.30 \mathrm{~mol} / \mathrm{L}$ とした. サンプル $\mathrm{E}$ は尿素および塩 化カルシウムの濃度を高めることで，より短期での固化 効果が期待できるかどうかの検証を目的としている.

\section{（3）供試体の作製}

長期試験に用いた供試体の概要を図-1 亿示す. 供試体 サイズは高さが $250 \mathrm{~mm}$, 直径が $90 \mathrm{~mm}$ の円筒を用い た. 供試体下部に高さを調整するために, 直径 $1 \mathrm{~mm} の$ ガラスビーズを $100 \mathrm{~g}$ 添加し, その上に不織布（前田工 繊 ジオフリース 400-s）を 2 枚被せた. その後, 含水比 を液性限界の 1.75 倍に調整した底泥を $700 \mathrm{~g}$ 静かに添 加し, ラップをかぶせて 3 日間の自然圧密を行った. 自 然圧密後, 純水 $250 \mathrm{~mL}$ をシリンジを用いて再䀣濁が起 こらないよう静かに添加し, その後, 表-1 に示した各サ ンプル A〜C の溶液およびウレアーゼをそれぞれ 350 $\mathrm{mL}$ ずつ添加した. 溶液およびウレアーゼを添加した後, 図-1 に示した攪拌機と濁度計を用いて濁度を測定した。 また，短期試験に用いた供試体の概要を図-2に示寸。
表-1 試験ケース別の配合

\begin{tabular}{|c|c|c|c|c|c|}
\hline \multirow{2}{*}{ サンプル } & \multicolumn{3}{|c|}{ 長期試験 } & \multicolumn{2}{|c|}{ 短期試験 } \\
\hline & A & B & $\mathrm{C}$ & $\mathrm{D}$ & $\mathrm{E}$ \\
\hline $\begin{array}{l}\text { Nutrient } \\
\text { Broth(g) }\end{array}$ & \multicolumn{2}{|c|}{0.00} & 3.00 & & \multirow{3}{*}{0.00} \\
\hline $\mathrm{NH}_{4} \mathrm{Cl}(\mathrm{g})$ & \multicolumn{2}{|c|}{0.00} & 10.00 & & \\
\hline $\mathrm{NaHCO}_{3}(\mathrm{~g})$ & \multicolumn{2}{|c|}{0.00} & 2.12 & & \\
\hline $\begin{array}{c}\mathrm{CO}\left(\mathrm{NH}_{2}\right)_{2} \\
(\mathrm{~g})\end{array}$ & \multicolumn{4}{|c|}{9.01} & $\begin{array}{c}18.02 \\
(0.30 \mathrm{~mol} / \mathrm{L})\end{array}$ \\
\hline $\mathrm{CaCl}_{2}(\mathrm{~g})$ & \multicolumn{4}{|c|}{$\begin{array}{c}16.65 \\
(0.15 \mathrm{~mol} / \mathrm{L})\end{array}$} & $\begin{array}{c}33.29 \\
(0.30 \mathrm{~mol} / \mathrm{L})\end{array}$ \\
\hline $\begin{array}{c}\text { ウレアーゼ } \\
\text { (g) }\end{array}$ & 0 & & 0.07 & & 4.00 \\
\hline 純水(mL) & & & & 00 & \\
\hline
\end{tabular}

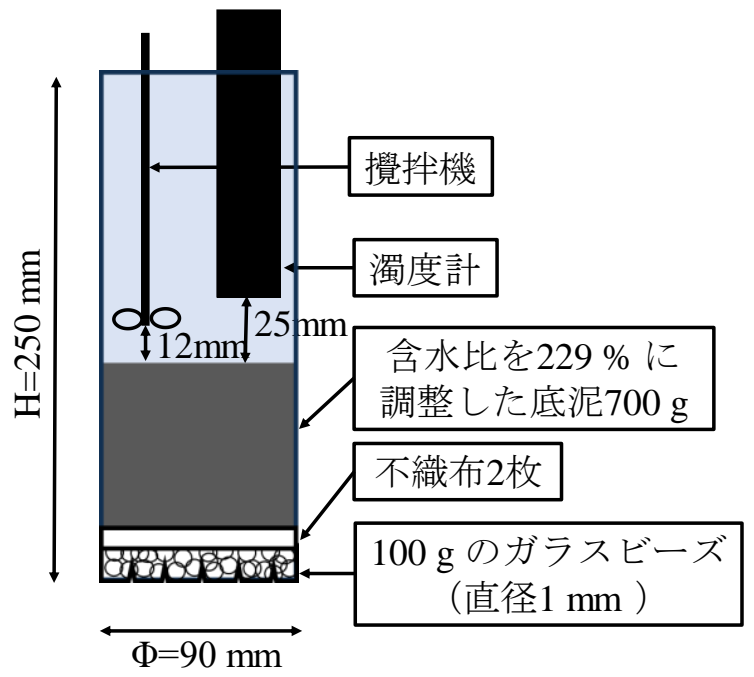

図-1＼cjkstart長期試験における供試体作製の略図

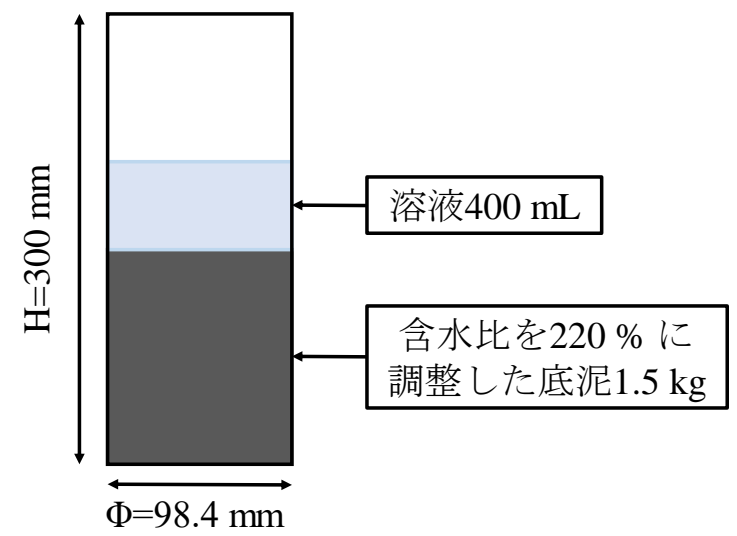

図-2＼cjkstart短期試験における供試体作製の略図 
供試体サイズは高さが $300 \mathrm{~mm}$ ，直径が $98.4 \mathrm{~mm}$ の円 筒である. 長期試験時と同様に含水比を液性限界の 1.75 倍に調整した底泥を $1.5 \mathrm{~kg}$ 添加し, ラップをして 3 日 間の自然圧密を行った. 自然圧密を行った後, 表-1 に示 したサンプル D，E の溶液およびウレアーゼをそれぞれ 底泥が乱れないように静かに添加した。

\section{3. 長期試験の結果と考察}

\section{（1）濁度試験による固化処理後の濁度測定}

自然圧密を行い，サンプル $\mathrm{A} \sim \mathrm{C}$ の溶液を $350 \mathrm{~mL}$ 添 加した後, 図-1 に示した攪汼機（600G ヘイドン）と濁 度計 (笠原理化工業株式会社 TR-52 測定可能範囲 0-220 $\mathrm{ppm}$ ）を用いて，攪拌機の回転数が $360 \mathrm{rpm}$ で 5 分攪 拌した後に初期濁度の測定を行った。初期濁度測定後は 7 日ごとに再度濁度を測定し, 濁度が $50 \mathrm{ppm}$ まで低下 していなかった場合, サンプル $\mathrm{A} \sim \mathrm{C}$ の溶液を再度添加 した. これを最大 28 日間で, 濁度が $50 \mathrm{ppm}$ 以下とな るまで繰り返し行った。 なお，濁度測定時には外部から の影響を防ぐことを目的として円筒全体をアルミホイル で覆うことにより遮光処理を施している. 図-3に濁度の 測定結果を示す.初期の濁度はサンプル A〜C において, 濁度計の測定可能範囲である $220 \mathrm{ppm}$ を上回っていた。 図より, サンプル A では4 回溶液を添加したが, 目標濁 度までの低下は見られなかった。 一方でサンプル B で は 1 回の溶液添加によって濁度が $50 \mathrm{ppm}$ 以下の 15.5 ppm まで低下寸る効果が確認された. また, サンプル C は 1 回目の添加では, カルサイト膜が剥がれてしまい, 濁度低下は確認されなかったが，2 回の添加で濁度が $50 \mathrm{ppm}$ まで低下し目標濁度に達したことが確認された。 サンプル A より, 酵素製剤を添加しない場合は濁度が 低下しないことが明らかとなった. また, サンプル B， C より，酵素製剂を添加した場合は濁度低下一の即効性 があることが明らかとなった。 しかし，微生物効果を期 待したサンプル C においては, 目標濁度までの低下は 確認されたが，酵素製剂の効果が大きく, 微生物活性の 効果は確認されなかった.

\section{（2） 溶液中の $\mathrm{NH}_{4}^{+} ， \mathrm{Ca}^{2+}$ 濃度測定}

試験期間中は，期待している尿素の加水分解およびカ ルサイトの析出が行われているかの確認を目的として溶 液中の $\mathrm{NH}_{4}{ }^{+}$および $\mathrm{Ca}^{2}{ }^{+}$濃度の測定を行った．溶液中の $\mathrm{NH}_{4}{ }^{+}$および $\mathrm{Ca}^{2+}$ 濃度の測定は濁度試験を行う直前にシリ ンジにより採取したサンプルを対象に行うこととした.

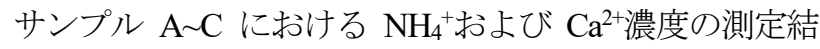
果を図-4 に示す. 図より, 濁度試験において目標濁度ま での低下が確認されなかったサンプル $\mathrm{A}$ では, $\mathrm{NH}_{4}{ }^{+} お ~$
よび $\mathrm{Ca}^{2+}$ 濃度の増減が他のサンプルに比べ遅いことが確 認された. これは, 微生物による尿素の加水分解反応は 働いているが, 酵素製剂と比較すると反応が遅く, $\mathrm{Ca}^{2+}$ 濃 度についても減少していないことから，カルサイト膜の 生成が行われず, 結果として濁度が低下しなかったため と考えられる. 一方で, サンプル $\mathrm{B}, \mathrm{C}$ に着目寸ると, サンプル $\mathrm{A}$ に比べ, $\mathrm{NH}_{4}{ }^{+}$濃度が上昇し, $\mathrm{Ca}^{2+}$ 濃度が大幅 に減少していることから, 尿素の加水分解反応が生じ, カルサイトが析出していると考えられる. また, サンプ ル C における初期の $\mathrm{NH}_{4}{ }_{4}$ 濃度が他のサンプルに比べ高 い理由としては, 微生物活性化を目的として塩化アンモ ニウムを添加したことが影響していると考えられる.

\section{(3) テンションメーターによる強度の測定}

濁度試験において，目標濁度の $50 \mathrm{ppm}$ まで低下した 後に強度測定を行った. テンションメーター（IMADA ZTS-100N）を用いて，テンションメーターの先端に直径 が $24 \mathrm{~mm}$, 先端角が $84^{\circ}$ のコーンを取り付け, 表層 から $20 \mathrm{~mm}$ までコーンを底泥と垂直となるように差し 込んだ際の最大押込み強さを計測した. 計測は 3 箇所行 い，強度はその平均值としている。

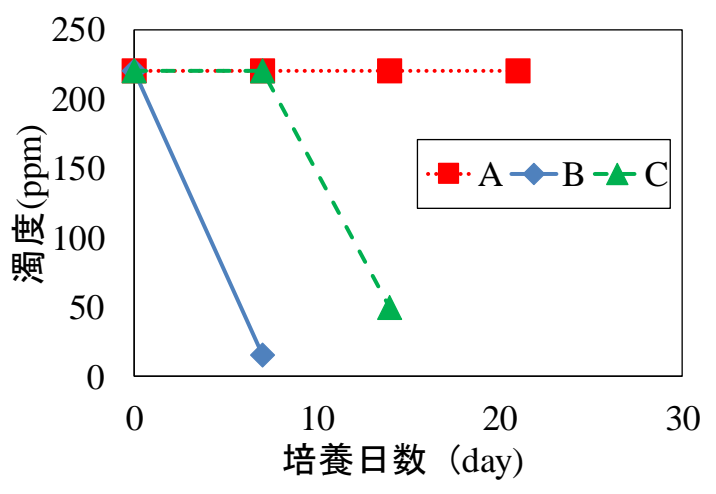

図-3 各ケースにおける濁度変化

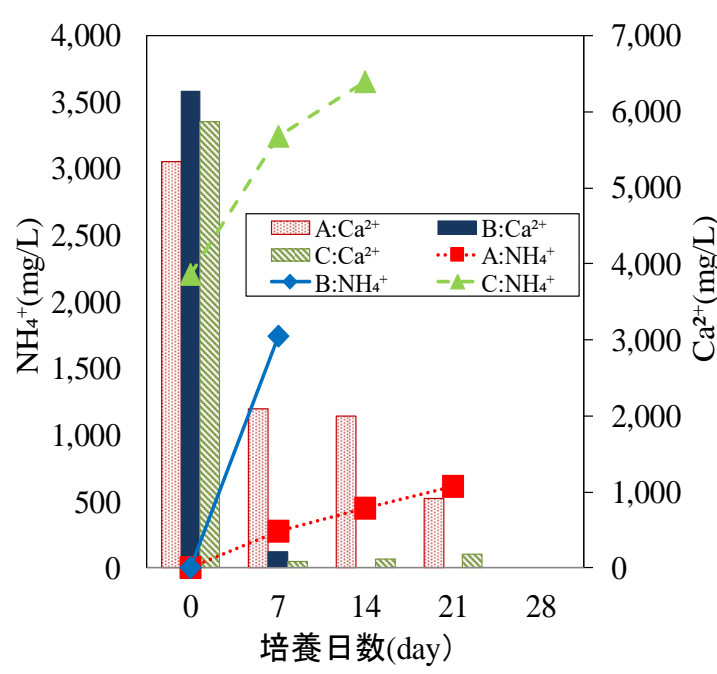

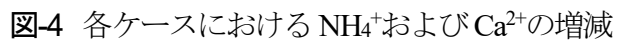


また，最大押込み強さを測定する直前に外面から定規を 用いて目視で生成されたカルサイトの膜厚を測定した. サンプル A では目視によるカルサイト膜が確認されな かったため, 強度測定は行っていない，一方で，サンプ ル B ではカルサイトの膜厚が $1.0 \mathrm{~mm}$, 強度が $0.47 \mathrm{~N}$, サンプル C ではカルサイトの膜厚が $1.7 \mathrm{~mm}$, 強度が $1.15 \mathrm{~N}$ であり, 膜厚が厚いほど強度が増加することが確 認された.これらの結果より, カルサイト膜が $1.0 \mathrm{~mm}$ ， 強度が $0.47 \mathrm{~N}$ 以上あれば蜀度を低下させ，巻き上がり を抑制可能であると考えられる.

\section{（4） ベーンせん断試験による底泥内強度の測定}

底泥固化処理を行ったサンプル $\mathrm{A} \sim \mathrm{C}$ と末処理の計 4 サンプルについてベーンせん断試験（JGS1411-2012）を 行った結果を図-5 に示寸. 試験は表層に生成されたカル サイトの膜を取り除いた後にベーンブレードの上端が隠 れるまで底泥に垂直に押し込み測定した。測定箇所とし ては，表層から $0-2 \mathrm{~cm} ， 2-4 \mathrm{~cm} ， 4-6 \mathrm{~cm}$ 付近で 1 ケ 所ずつ計 3 点においてベーンブレードを抜かずに測定 を行った．測定は，回転速度が $6^{\circ} / \mathrm{mm}$ ，回転角度が $0^{\circ}$ から $30^{\circ}$ の条件で行った. 図より, 寸べての固化 処理後の供試体においてベーンせん断強度がゴカイ等の 底生生物の活動範囲である $1.2 \mathrm{kN} / \mathrm{m}^{2}$ 以下であることが 確認された ${ }^{4}$. この結果より, 固化処理後の底泥内強度 は底生生物の生活範囲内であり，影響は少ないものであ ると考えられる.

\section{4. 短期試験の結果と考察}

\section{(1) 短期試験の方法および手順}

長期試験において，ウレアーゼと尿素，塩化カルシウ ム溶液を添加したサンプル $\mathrm{B}$ が最も短期間での巻き上 がり抑制が可能であることが明らかとなった. そのため, ウレアーゼの添加量，尿素，塩化カルシウムの濃度を高 くすることで，より短期間での固化効果に期待した短期 試験を行った. 供試体の概要は図-2 に示寸とおりである. 供試体作製後, 乳鉢ですりつぶしたウレアーゼと表-1 に 示したサンプル D, E の溶液をそれぞれ $400 \mathrm{~mL}$ 添加し 一日養生させた. その後, $\mathrm{NH}_{4}{ }^{+}$および $\mathrm{Ca}^{2+}$ 濃度を測定し, $\mathrm{Ca}^{2+}$ が半分以上消費されていた場合は溶液を供試体上部 より排水後，再びサンプル D，E の溶液をそれぞれ 400 $\mathrm{mL}$ 添加した。これをカルサイトの膜厚が $2 \mathrm{~mm}$ 程度に 達するまで繰り返し行った。 この膜厚が $2 \mathrm{~mm}$ 程度に達 した際にはテンションメーターによる強度の測定および $\mathrm{X}$ 線 $\mathrm{CT}$ 撮影を行い, 固化溶液濃度がカルサイト膜に及 ぼす影響について検証を行ったななお，長期試験の結果 よりカルサイト膜が $1.0 \mathrm{~mm}$ ，強度が $0.47 \mathrm{~N}$ 以上あれ
ば，巻き上がりを抑制可能であることが明らかとなって いる．短期試験においては，この膜厚が $2 \mathrm{~mm}$ 程度に達 するまで試験を行うことから，巻き上がりを抑制するに は十分な膜厚であると判断し濁度試験を省略した。

\section{（2） 溶液内の $\mathrm{NH}_{4}^{+} ， \mathrm{Ca}^{2+}$ 濃度測定}

サンプル D，E では．溶液を添加から 1 日養生後の 供試体の上澄み液を採取し, 溶液中に含まれる $\mathrm{NH}_{4}{ }^{+} お よ$ び $\mathrm{Ca}^{2+}$ 濃度の測定を行った. 培養日数ごとにおける $\mathrm{NH}_{4}{ }^{+}$ および $\mathrm{Ca}^{2+}$ 濃度の測定結果を図-6 に示寸。サンプル $\mathrm{D}$ では培養日数が $0 ， 1 ， 3$ 日目に，サンプル E は培養日 数 0,1 日目に溶液を再度添加した. 図より, $\mathrm{NH}_{4}{ }^{+}$が増 加寸るにつれて, $\mathrm{Ca}^{2+}$ 濃度が減少傾向にあることから, 尿 素の加水分解反応が生じ，炭酸カルシウムが結晶となっ て沈殿していると考えられる.

\section{（3） テンションメーターによる強度の測定}

膜厚が $2 \mathrm{~mm}$ 程度に達した際に，長期試験と同様の手 法で強度の測定を行った。 サンプル D は培養 4 日目, サンプル E は培養日数が 3 日目で膜厚が約 $2 \mathrm{~mm}$ に達

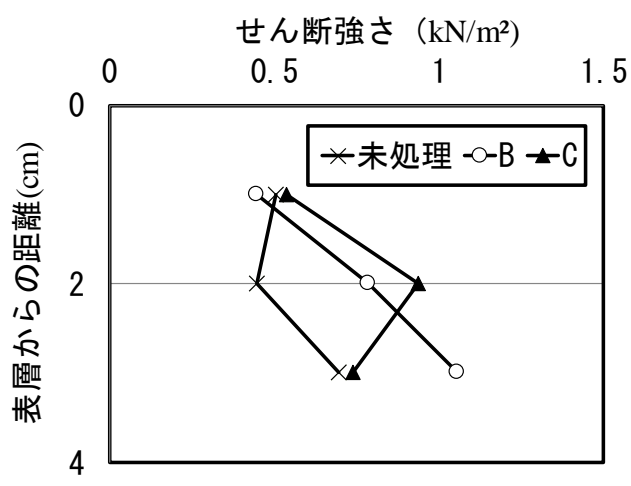

図-5 ベーンせん断試験結果

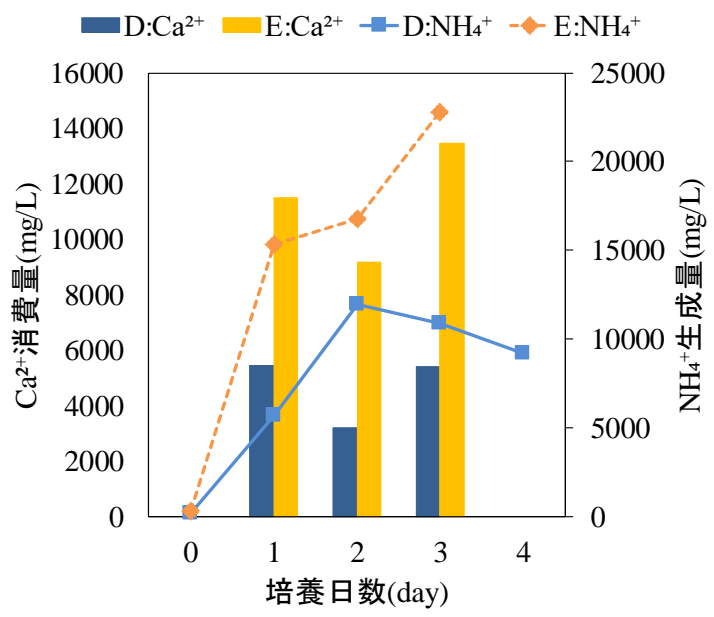

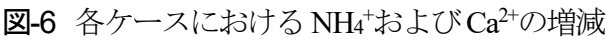


したことが確認された。 また，強度測定を行った結果， サンプル D では膜厚が $1.8 \mathrm{~mm}$ ，強度が $2.9 \mathrm{~N}$ ，一方 で，サンプル E では膜厚が $2.2 \mathrm{~mm}$, 強度が $3.1 \mathrm{~N}$ と なった.ここで，長期試験および短期試験における膜厚 と強度の関係についてまとめたものを図-7 に示す.これ らの結果より, 尿素, 塩化カルシウム溶液の濃度を高く すると，カルサイトの膜厚が厚くなること，長期試験と 同様に，カルサイト膜が厚くなるほど強度が増加する傾 向があることが確認された. サンプル E はサンプル D と比較し, 強度が $0.2 \mathrm{~N}$ 増加するが, $10000 \mathrm{mg} / \mathrm{L}$ 多く $\mathrm{NH}_{4}{ }^{+}$を排出していることを考慮すると, 酵素製剤の濃度 が $1.6 \mathrm{~g} / \mathrm{L}$ のとき, サンプル D が適当であると考えられ る.

\section{(4) X 線 CT 撮影によるカルサイト膜の観察}

写真-1 および写真-2 に示すとおり, サンプル $\mathrm{D}, \mathrm{E}$ において, 表層に析出したカルサイト膜と底泥の間に隙 間が生じていることが確認された，そのため，より詳細 な情報を得ることを目的として X 線 CT 撮影を行うこ ととした，撮影結果を図-8，図-9 に示す，なお，装置は 港湾空港技術研究所が所有する X 線 CT 装置 5) を用い て、X 線 CT 撮影条件は $120 \mathrm{kV}, 120 \mu \mathrm{A}$ としてい る. 図より, 高密度領域として白く表示されているカル サイトの層と, カルサイトよりも低密度領域として死色 で示されている底泥との間に，空気もしくは水と考えら れる黒い隙間が生じていることが明らかとなった. また, サンプル D , E の隙間の大きさに着目すると, 写真1, 写真-2 からもわかるとおり, サンプル E の方がサン プル D に比べ，より隙間が大きいことが明らかとなっ た．隙間ができた原因としては，粘土の自重圧密による 影響が考えられる. あわせて，表層に生成されたカルサ イトの膜に着目すると，サンプル D， E ともに，供試体 の外側付近(図-8 中の赤丸)でより白く見えることから， 炭酸カルシウムは円筒の内周面付近に多く析出, 沈殿し ていることが考えられる.

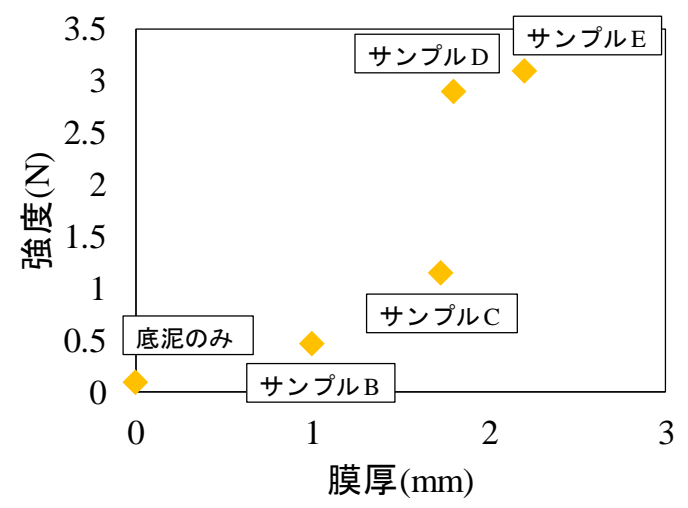

図-7 カルサイト膜の強度と膜厚の関係

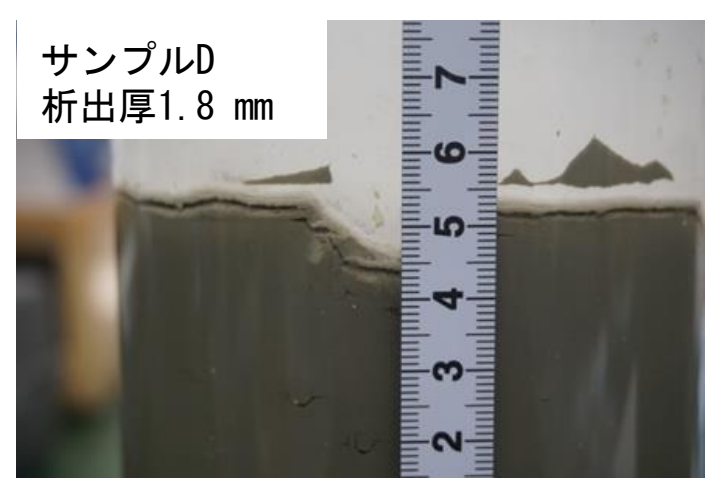

写真-1 サンプル D における表層状況

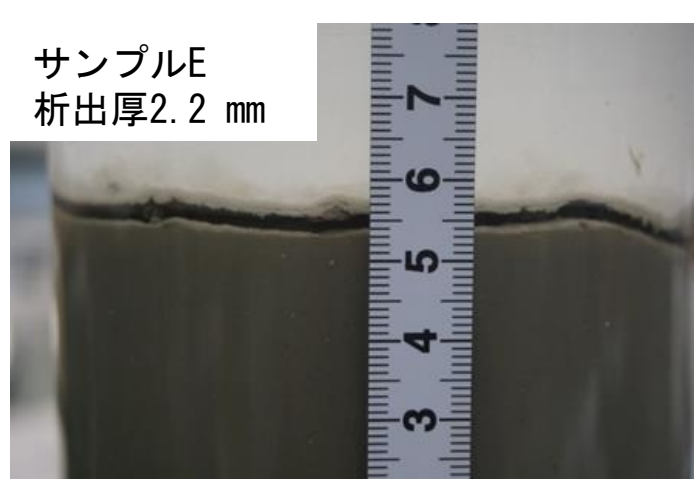

写真-2 サンプルEにおける表層状況

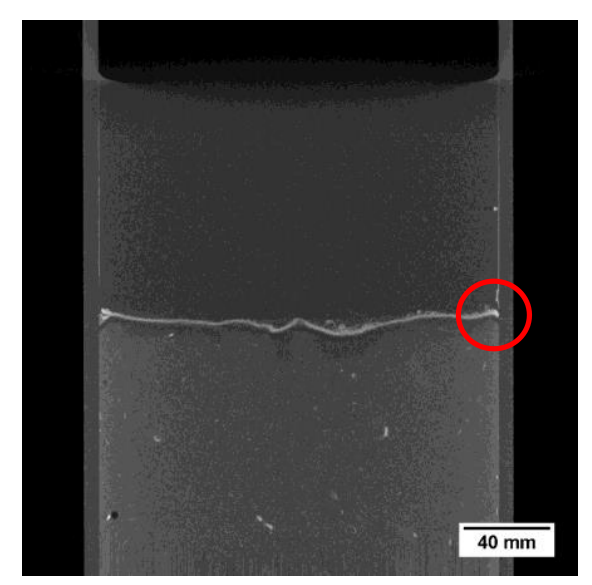

図-8 サンプル D における CT 撮影結果

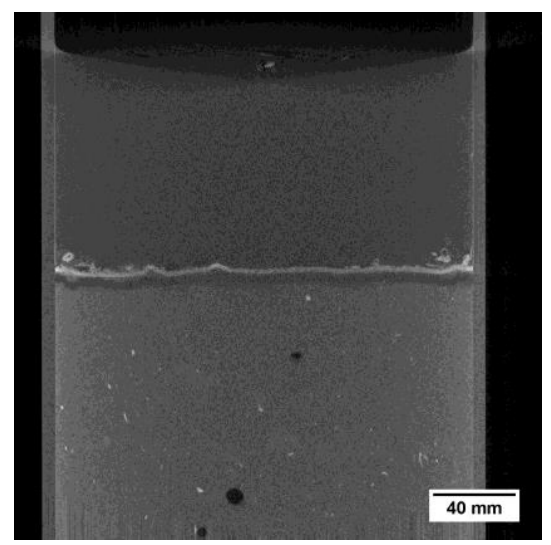

図-9サンプルEにおける CT 撮影結果 


\section{5. 結論}

本研究では，表層固化に基づく再乿濁抑制技術の適用 範囲拡大を目的とし，微生物ではなく酵素そのものを反 応触媒として用いる酵素触媒法の有効性について検討し た. 具体的には，短期および長期での固化効果を想定し た 2 ケースの室内試験を行った. 濃度が $0.07 \mathrm{~g} / \mathrm{L}$ の低濃 度のウレアーゼを添加し，長期的な施工を目的とした長 期試験では, 組成が異なる 3 種類の溶液を用いて供試体 を作製し，濁度低下による巻き上がり抑制を評価するた めの濁度試験, 添加した溶液内の $\mathrm{NH}_{4}^{+}$および $\mathrm{Ca}^{2+}$ 濃度 の測定，テンションメータ一による底泥表層に析出され たカルサイト膜の強度測定およびベーンせん断試験を行 った. 続いて, 長期試験で得られた知見をもとに，より 短期的な効果を期待した確認試験を行った。短期試験は 溶液中の $\mathrm{NH}_{4}^{+}$および $\mathrm{Ca}^{2+}$ 濃度の測定，テンションメー タ一による底泥表層に析出されたカルサイト膜の強度測 定および X 線 CT 撮影による底泥表層状況についての 観察を行った. これらの 2 種類の試験を行った結果, 以 下の知見が得られた。

(1)長期試験から， $0.15 \mathrm{~mol} / \mathrm{L}$ の尿素および塩化カルシウ ム溶液とウレアーゼを添加した場合，最も短期的に濁度 を低下させ，巻き上がりを抑制することが可能である.

(2)固化処理後の底泥内強度は底生生物であるゴカイ等 の活動可能範囲である $1.2 \mathrm{kN} / \mathrm{m}^{2}$ を下回っていたため, 底生生物への影響は低いものであると考えられる。

(3) 底泥表層に生成されたカルサイトの膜厚と，その強度 の関係から，膜厚が厚くなるほど強度は増加することが 明らかとなった。

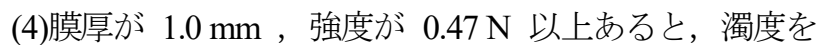
低下させ，巻き上がりを抑制させることが期待できる. (5)短期試験から，サンプル E はサンプル D に比べ, 強 度は $0.2 \mathrm{~N}$ 高いが，多くのNH+2生成していることから， サンプル D がより適切であると考えられる.

(6)X 線 CT 撮影により，カルサイト膜と底泥の間にわ ずかな隙間が生じていること，カルサイトの膜厚は供試 体の外側部分に多く析出していることが明らかとなった.

謝辞 : 本研究の一部は科学研究費補助金 $(A)$ 課題番号 15H02634 の補助を受けて実施された。

\section{参考文献}

1) 高山知司, 吉岡洋，田邊義隆，大和剛 : 波浪・潮流に よる大阪湾底泥の巻き上がり特性, 海洋開発論文集, P.117-122， 2001.

2) 白石修章，飯島眞治，永野国松，中辻啓二 : 関西国際 空港沖における潮流と波による底泥の巻き上げ現象, 海岸工学論文集，p.1076-1080，2000。

3) 川崎稀文，畠俊郎：湖沼底泥の固化技術による巻きあ がり抑制の検討: 土木学会中部支部講演概要集, p.305306,2017

4) 畠俊郎，入江光輝：チュニジア国 Joumine 貯水池底泥 を活用したイシュケウル湖の湖底環境復元技術の適 用性評価，土木学会論文集 $\mathrm{G}$ (環境)，p.125-133，2015.

5) 松村聡, 水谷崇亮, 篠永龍毅：マイクロフォーカス X 線 CT スキャナを用いた地盤工学への新たなアプローチ，港 空研資料，No.1313，2015.

\section{EVALUATION OF APPLICABILITY OF BOTTOM MUD CURLING SUPPRESSION TECHNOLOGY BY ENZYME CATALYTIC METHOD FOR SEAFLOOR SEDIMENT}

\section{Yusui MURATA, Toshiro HATA, Shintaro KAGIMOTO, Satoshi MATSUMURA and Takaaki MIZUTANI}

It is a problem that sediment flows out by rolling up the bottom mud. Based on the results of previous studies, the effectiveness of superficial solidification technology using enzymes derived from microbial functions has been clarified from the study of Lake Ichkeul in Tunisia. Therefore, in this research, for the purpose of evaluating the applicability of this technology to domestic and shortening the construction period, we examined the effectiveness of the proposed technology by the enzyme catalytic method for domestic surface sediments. In the test, two cases of specimens for long-term construction and shortterm construction were prepared. According to the results of the test, it became clear that turbidity suppression by enzyme catalytic method for domestic sediments is possible. In addition, CT imaging revealed that as the thickness of the calcite membrane deposited on the surface layer of the sediment became thicker, the surface strength increased and gaps were formed between the calcite and the bottom mud. 